\title{
1 RADIOACTIVE LABELING AND FRACTIONATION OF FISSION YEAST WALLS
}

2 Pilar Pérez and Juan C. Ribas*

3 Instituto de Biología Funcional y Genómica, Consejo Superior de Investigaciones Científicas (CSIC) /

4 Universidad de Salamanca, 37007 Salamanca, Spain

5

6 Short tittle: cell wall polymers analysis

7

$8 \quad$ Key words: cell wall; polysaccharides; $\beta$-glucan, $\alpha$-glucan; mannan, Bgs.

9 *Corresponding author:

10 Phone: (34) 923-294898

11 Fax: (34) 923-224876

12 E-mail: ribas@usal.es

13 


\section{ABSTRACT}

Fungal cells contain an essential structure external to the cell, made of polysaccharides and

3 proteins, termed cell wall. The polysaccharides represent about 96\% of the cell wall. They are

4 complex insoluble polymers connected to each other by covalent linkages and hydrogen bonds with

5 specific localizations in the cell wall and septum. Fission yeast contains three $\beta$-glucans, a mayor

6 branched $\beta(1,3)$-glucan, a minor linear $\beta(1,3)$-glucan and a minor branched $\beta(1,6)$-glucan; two $\alpha$ -

7 glucans, a mayor $\alpha(1,3)$-glucan and a minor $\alpha(1,4)$-glucan; and a minor amount of galactomannan-

8 linked glycoproteins. We provide here a simple protocol to label uniformly the cell wall using [U-

$\left.9{ }^{14} \mathrm{C}\right]$-glucose as carbon source and to fractionate the cell wall into the three or four main cell wall

10 components: galactomannoproteins, $\alpha$-glucan and $\beta$-glucan, or $\beta(1,3)$-glucan and $\beta(1,6)$-glucan. This

11 simple protocol uses enzymatic and chemical fractionations of the different cell wall components that

12 permit the quantification of each polysaccharide in the cell wall and in the cell. This protocol is very

13 useful for the analysis of the many morphological alterations caused by a variety of cellular processes

14 that ultimately affect the cell wall and thus cell morphogenesis.

15

16 


\section{Reagents}

Citrate-phosphate buffer 500 mM, pH 5.6 (10x).

$71 \mathrm{~g} / \mathrm{Na}_{2} \mathrm{HPO}_{4}, 115 \mathrm{~g} / \mathrm{l}$ citric acid, adjust the $\mathrm{pH}$ with $5 \mathrm{M} \mathrm{NaOH}$.

D-[U- $\left.{ }^{14} \mathrm{C}\right]$ glucose (Hartmann Analytic).

EDTA, 1mM.

Ethanol.

Fehling's reagent (Algranati et al. 1966).

This reagent must be prepared fresh for each experiment by adding one volume of reagent $B$ $\left(3.5 \% \mathrm{CuSO}_{4}\right)$ to one volume of reagent $A(17.3 \%$ potassium sodium tartrate dissolved in $12.5 \% \mathrm{KOH})$ and mixing well. Reagents $A$ and $B$ can be stored at room temperature for months.

$\mathrm{HCl} 6 \mathrm{~N}$.

Liquid scintillation cocktail (Perkin Elmer).

$\mathrm{NaOH}, 12 \%$.

Potassium phosphate monobasic $500 \mathrm{mM}, \mathrm{pH} 7.5$ (10x).

$$
\text { Adjust the } \mathrm{pH} \text { with } 5 \mathrm{M} \mathrm{KOH} \text {. }
$$

Quantazyme (MP Biomedicals; Q-Biogene; Quantum Biotechnologies). Alternatively, Lyticase from Oerskovia Xanthineolytica (Sigma-Aldrich).

It is a recombinant endo- $\beta(1,3)$ glucanase from Oerskovia Xanthineolytica (Kapteyn et al. 1997; Kollar et al. 1997). Stock of 20,000 units/ml in $50 \mathrm{mM}$ potassium phosphate monobasic, $p H 7.5$, stored at $-20^{\circ} \mathrm{C}$.

Recombinant $\beta(1,3)$ glucanase Yeast Lytic Type (Wako Pure Chemical Industries) can be used instead of Quantazyme. It is a recombinant endo- $\beta(1,3)$ glucanase from Arthrobacter sp. It is similar to Quantazyme (100 units per assay) and it is active in Quantazyme buffer.

Trichloroacetic acid (TCA), $10 \%$.

Yeast mannan (Sigma-Aldrich).

Used as the carrier. Stock of $50 \mathrm{mg} / \mathrm{ml}$ in water, stored at $-20^{\circ} \mathrm{C}$.

Zymolyase-100T or Zymolyase-20T (AMS Biotechnology; MP Biomedicals; Seikagaku Biobusiness Corporation).

Stock of $5 \mathrm{mg} / \mathrm{ml}$ in $50 \mathrm{mM}$ citrate-phosphate, $\mathrm{pH}$ 5.6, stored at $-20^{\circ} \mathrm{C}$.

They are partially purified preparations from Arthrobacter luteus with $\beta(1,3)$ glucanase, protease, and mannanase activities. They do not contain $\alpha$-glucanase activity.

Kitalase (Wako Pure Chemical Industries). Also named Yeast Lytic Enzyme from Rhizoctonia solani (MP Biomedicals) or Lysing Enzymes from Rhizoctonia solani (SigmaAldrich), can be used instead of Zymolyase-100T or 20T. It has $\beta(1,3)$-glucanase, hemicellulase, pectinase, protease, and amylase activities but does not contains $\alpha(1,3)$ glucanase activity. It is active in $60 \mathrm{mM}$ potassium-acetate, pH 5.0. Stock of $100 \mathrm{mg} / \mathrm{ml}$ in 60 $m M$ potassium-acetate, $\mathrm{pH} 5.0$, stored at $-20^{\circ} \mathrm{C}$. 


\section{Equipment}

Cell disrupter FastPrep FP120 (MP Biomedicals; Q-Biogene; Thermo Scientific).

Centrifuge for 10-ml tubes.

Centrifuge microfuge for 2.0- or 1.5-ml tubes.

Flasks, 100-, 50- and 25-ml.

Glass beads, $0.5 \mathrm{~mm}$ diameter.

Glass microfiber filter discs, grade GF/C, $25 \mathrm{~mm}$ diameter (Whatman).

Glass vacuum microanalysis filter holder (Millipore), consisting of:

- Filtering flask (500-ml recommended to hold large volume and avoiding $\left[{ }^{14} \mathrm{C}\right]$ contamination of the vacuum pump system).

- Perforated silicone stopper.

- Borosilicate glass base.

- Removable stainless steel screen filter support (do not use fritted glass screen support because it will filter the samples more slowly).

- Borosilicate glass funnel, 15-ml.

- Spring Clamp, $25 \mathrm{~mm}$, aluminum.

- Connector tube to vacuum source.

Heat block (or beaker with water on a heater)

Liquid scintillation counter (Perkin Elmer).

Liquid scintillation vials.

Roller of tubes (in a $37^{\circ} \mathrm{C}$ incubator).

Shaker.

Spectrophotometer.

Thermomixer.

Tubes, borosilicate, 3-ml, and plastic, 10-ml.

Vacuum pump.

Vortex.

\section{METHOD}

32 This protocol is essentially as described (Pérez and Ribas 2004; Muñoz et al. 2013), with some modifications to improve it and make it simpler. It is important to follow the indications of your 
1 institution's Environmental Health and Safety Office for proper handling of equipment and radioactive

2 material used in this protocol.

\section{Radiolabeling of cells}

1. Prepare early log-phase cells growing in liquid medium (YES, YPD, MM, etc) and temperature similar to the medium where $\left[\mathrm{U}-{ }^{14} \mathrm{C}\right]$ glucose will be added.

The efficiency of labeling will depend on the glucose concentration in the medium. Thus for higher efficiency, media with $1 \%$ or $0.5 \%$ glucose can be used.

2. Dilute the cells in $15 \mathrm{ml}$ of medium calculating that at the end of the experiment the cells should be collected in log-phase, at about $1-1.5 \times 10^{7}$ cells $/ \mathrm{ml}\left(\mathrm{A}_{600}=0.7-1.0\right)$.

3. Take $7 \mathrm{ml}$ of the diluted cells into a new flask and add $3 \mu \mathrm{Ci} / \mathrm{ml}$ of $\left[\mathrm{U}_{-}{ }^{14} \mathrm{C}\right]$ glucose. For a high labeling, overnight cell growth or a period allowing at least 3 or 4 cell cycles is desirable.

If a stronger labeling is required, as for example short period of growth (3-6 h) at restrictive temperature, labeling can be raised to $10-15 \mu \mathrm{Ci} / \mathrm{ml}$.

Note that label incorporation is progressive and thus, the amount of radioactivity incorporated into the cells will increase $50 \%$ in each cell cycle. If the cell is expressing a constitutive phenotype, the labeling will not change with the time of incubation and thus radioactivity could be added at any time. However, for thermosensitive strains or gene repression experiments, the cell wall defects will increase with time. If $\left[\mathrm{U}_{-}{ }^{14} \mathrm{C}\right] \mathrm{glucose}$ is added too early (close to the temperature shift or start of repression) the cell will incorporate radioactivity under permissive conditions and the incorporation into the defective polymer will only decrease with each cell cycle. This initial labeling will attenuate the real data of cell wall defects. In these cases, it is recommended to label the cells for a short period as close as possible to the collection time, as much as 3-6 h, or 12 cell cycles, and using a higher concentration of $\left[\mathrm{U}_{-}{ }^{14} \mathrm{C}\right]$ glucose to overcome the 50$75 \%$ maximal labeling of cell wall in these $1-2$ cycles.

4. Incubate both hot (radioactive) and cold flasks of each cell culture at the desired temperature and use the cold cell culture to monitor cell growth. 
5. Prepare previously a stock of wild-type cells that will be used as the carrier: Incubate wild-type cells in $100 \mathrm{ml}$ of YES medium at $28^{\circ} \mathrm{C}$ for $48 \mathrm{~h}$ until late stationaryphase. Collect the cells 5 min at 4,000xg, wash once with 20-40 ml of distilled water, and resuspend the cells in $10 \mathrm{ml}$ of $1 \mathrm{mM}$ EDTA, $0.02 \%$ Na azide. This is approximately $10^{10}$ cells $/ \mathrm{ml}$. The carrier cells can be stored at $4^{\circ} \mathrm{C}$ for weeks.

\section{Cell wall isolation}

1. Monitor the cold cell culture until it reaches the appropriate early log-phase, usually $1-1.5 \times 10^{7}$ cells $/ \mathrm{ml}\left(\mathrm{A}_{600}=0.7-1.0\right)$. At that time collect $6 \mathrm{ml}$ of hot cell culture (out of the initial 7-ml cell culture) in 10-ml tubes. Centrifuge $5 \mathrm{~min}$ at $4.000 \mathrm{xg}$. Carefully decant the cells, keeping some supernatant to avoid loss of cells with the last drops of supernatant, and dispose of the radioactive medium in the appropriate radioactive containers.

2. Supplement the labeled cells with $300 \mu \mathrm{l}$ of unlabeled cells used as the carrier (see above, Step I.5). Mix the cells.

Carrier cells will minimize any loss of labeled cells or cell wall material during processing.

3. Wash the cells twice with $10 \mathrm{ml}$ of $1 \mathrm{mM}$ EDTA and resuspend them in $1.1 \mathrm{ml}$ of $1 \mathrm{mM}$ EDTA.

Due to cell homing, the final volume will be above $1.1 \mathrm{ml}$. This will permit taking precisely $1 \mathrm{ml}$ for cell processing and $2 \times 50 \mu$ for measuring the cell labeling from the higher volume of cell suspension.

4. Take two 50- $\mu \mathrm{l}$ aliquots of cells and add them to $2 \mathrm{ml}$ of liquid scintillation cocktail in liquid scintillation vials. Mix and keep at room temperature. The radioactivity of the samples can be analyzed later (in Step IV.11 bellow) and corresponds to the TOTAL CELL INCORPORATION fraction (Fig. 1A). 
5. Take a 1-ml aliquot of cells and transfer it to a $1.5-\mathrm{ml}$ tube, centrifuge $5 \mathrm{~min}$ at $5,000 \mathrm{xg}$ and resuspend the cells in $100 \mu \mathrm{l}$ of $1 \mathrm{mM}$ EDTA. Add glass beads until they cover the entire cell volume.

6. Break the cells in a cell disrupter (FastPrep FP120: 3 pulses of $20 \mathrm{~s}$ each at a shaking speed of 6.0 and $\left.4^{\circ} \mathrm{C}\right)$.

7. Transfer the glass beads and cell debris to a $10-\mathrm{ml}$ tube by adding $600 \mu \mathrm{l}$ of $1 \mathrm{mM}$ EDTA, vortexing it, and quickly pouring it into the 10-ml tube. Repeat the process until all the glass beads and cell debris have been transferred to the 10-ml tube. Wash the tube once more. This will minimize the loss of cell debris.

8. Vortex the 10-ml tube, carefully collect the cell debris supernatant, and transfer it into a new 10-ml tube. Wash the glass beads several times with $500 \mu \mathrm{l}$ of $1 \mathrm{mM}$ EDTA and transfer it to the new 10-ml tube.

This step is important for collecting all residual material.

9. Add $1 \mathrm{mM}$ EDTA to complete $10-\mathrm{ml}$ volume, mix it, and centrifuge $5 \mathrm{~min}$ at $1,500 \mathrm{xg}$.

This low-speed centrifugation will precipitate the cell walls but not other insoluble cell debris. The supernatant will appear turbid and dense and it should be removed carefully.

10. Wash three times with $5 \mathrm{ml}$ of $5 \mathrm{M} \mathrm{NaCl}$ and three times with $5 \mathrm{ml}$ of $1 \mathrm{mM}$ EDTA.

The high ionic strength washes will remove membranes attached to the cell wall material. The first supernatant usually appears turbid because of the high density of released membranes.

11. Resuspend the cell walls with $500 \mu \mathrm{l}$ of $1 \mathrm{mM}$ EDTA, $0.02 \% \mathrm{Na}$ azide and heat them at $95^{\circ} \mathrm{C}$ for $1 \mathrm{~h}$.

This will inactivate the intrinsic hydrolytic cell wall enzymes that could interfere with the wall analysis. Use a heat block or a heated beaker with water, and set the temperature accurately. Lower temperature may produce only partial enzymatic inactivation. Higher temperature may cause boiling of samples. 
12. Once the tubes are cooled at room temperature, the volume should be adjusted exactly to $1 \mathrm{ml}$ and the cell wall material resuspended to homogeneity. At this point the cell walls can be stored at $4^{\circ} \mathrm{C}$ for at least 2 weeks.

13. Take two 50- $\mu$ l aliquots of cell walls and add them to $2 \mathrm{ml}$ of liquid scintillation cocktail in liquid scintillation vials. Mix and keep at room temperature. The samples can be analyzed later (in Step IV.11 bellow) and correspond to the TOTAL CELL WALL INCORPORATION fraction (Fig. 1A).

III. Cell wall fractionation by enzymatic digestion

This method involves enzymes capable of specifically digest one or some cell wall polymers without altering the others.

\section{Zymolyase-100T degradation.}

Zymolyase-20T can also be used but it is 5-fold less active. Kitalase can also be used ( $200 \mu \mathrm{g}$, in $60 \mathrm{mM}$ potassium-acetate, $\mathrm{pH} 5.0)$. They are $\alpha(1,3)$-glucanase-free enzymatic complexes that degrade all the cell wall except $\alpha$-glucan.

- Take 4x $50 \mu \mathrm{l}$ aliquots of cell walls to 1.5 -ml tubes.

- Add $30 \mu \mathrm{l}$ of $500 \mathrm{mM}$ citrate-phosphate buffer, pH 5.6 (50 mM final concentration). - Add $25 \mu \mathrm{g}$ of Zymolyase-100T ( $5 \mu \mathrm{l}$ of a stock of $5 \mathrm{mg} / \mathrm{ml}$ ) in 2 aliquots.

- Add $5 \mu \mathrm{l}$ of distilled water in the two other aliquots.

These aliquots are the control for no enzymatic degradation.

- Complete all the aliquots with distilled water until $300 \mu \mathrm{l}$ and mix well.

- Incubate with shaking in a roller or a thermomixer at $37^{\circ} \mathrm{C}$ for $24 \mathrm{~h}$.

\section{Quantazyme degradation.}

Quantazyme is a recombinant endo- $\beta(1,3)$-glucanase that specifically degrades the cell wall $\beta(1,3)$-glucan. Recombinant $\beta(1,3)$-glucanase Yeast Lytic Type is also an endo- $\beta(1,3)$ glucanase with similar activity to that of Quantazyme. None contain contaminant activities.

- Take 4x $50 \mu \mathrm{l}$ aliquots of cell walls to 1.5 -ml tubes. 
- Add $30 \mu \mathrm{l}$ of $500 \mathrm{mM}$ potassium phosphate monobasic, $\mathrm{pH} 7.5$ (50 mM final concentration).

- Add $30 \mu \mathrm{l}$ of $600 \mathrm{mM} \beta$-mercaptoethanol (60 mM final concentration).

- Add 100 units of Quantazyme (5 $\mu$ l of a stock of 20,000 units/ml) in 2 aliquots.

- In the 2 other aliquots add $5 \mu \mathrm{l}$ of distilled water.

These cell wall samples without enzyme are the control for no enzymatic degradation.

- Complete with distilled water until $300 \mu \mathrm{l}$ and mix well.

- Incubate with shaking in a roller or a thermomixer at $37^{\circ} \mathrm{C}$ for $24 \mathrm{~h}$.

\section{Processing of the enzymatic reactions}

- Centrifuge the aliquots $5 \mathrm{~min}$ at 20.000xg and remove carefully the supernatant.

- Add $1 \mathrm{ml}$ of $10 \%$ TCA and keep at $4^{\circ} \mathrm{C}$ for at least $1 \mathrm{~h}$.

The samples can be stored at $4^{\circ} \mathrm{C}$ and filtered later.

- Filter the samples through glass fiber filters (Whatman GF/C).

It is important to wet the filter with $2 \mathrm{ml}$ of $10 \%$ TCA before adding the sample.

- Wash twice with $1 \mathrm{ml}$ of $10 \%$ TCA and once with $1 \mathrm{ml}$ of ethanol.

- Insert the filters into liquid scintillation vials and add $2 \mathrm{ml}$ of liquid scintillation cocktail.

- Measure the radioactivity of the samples in a liquid scintillation counter.

Pellets of Zymolyase-100T degradation correspond to the CELL WALL $\alpha$-GLUCAN fraction (Fig. 1A).

Pellets of Quantazyme degradation correspond to the CELL WALL MINUS $\beta(1,3)$-GLUCAN fraction (Fig. 1A).

\section{Chemical fractionation of galactomannan}


1 Although usually called galactomannan because it is the main component of the glycoproteins, this

2 fraction corresponds to galactomannoproteins.

1. Take $2 \times 200 \mu \mathrm{l}$ aliquots of cell walls to $10-\mathrm{ml}$ tubes with $200 \mu \mathrm{l}$ of $12 \% \mathrm{NaOH}$ and mix it to make $400 \mu \mathrm{l}$ of cell walls in $6 \% \mathrm{NaOH}$.

2. Heat the samples at $80^{\circ} \mathrm{C}$ for $1 \mathrm{~h}$ and cool them to room temperature. This alkali extraction solubilizes all the cell wall polysaccharides.

3. Centrifuge $5 \mathrm{~min}$ at $1,500 \mathrm{xg}$ and transfer the supernatants to new $10-\mathrm{ml}$ tubes.

4. Add $5 \mathrm{mg}(100 \mu \mathrm{l})$ of yeast mannan as the carrier and mix well.

5. Add 4 volumes $(1.6 \mathrm{ml})$ of freshly prepared Fehling's reagent (Algranati et al. 1966). Mix it well and keep overnight at $4^{\circ} \mathrm{C}$ to precipitate the galactomannan.

6. Centrifuge $10 \mathrm{~min}$ at $4,000 \mathrm{xg}$ and decant the galactomannan pellet. Wash twice with $3 \mathrm{ml}$ of Fehling's reagent.

7. Solubilize the pellet with $20-40 \mu \mathrm{l}$ of $6 \mathrm{~N} \mathrm{HCl}$ added drop by drop, mixing until solubilization.

8. Add $100 \mu \mathrm{l}$ of $50 \mathrm{mM}$ Tris-HCl, $\mathrm{pH} 7.5$ and mix well.

9. Transfer the samples of solubilized galactomannan to liquid scintillation vials containing $2 \mathrm{ml}$ of liquid scintillation cocktail.

10. Wash the tubes twice with $100 \mu \mathrm{l}$ of $50 \mathrm{mM}$ Tris- $\mathrm{HCl}, \mathrm{pH} 7.5$, add it to the corresponding liquid scintillation vials, and mix well.

11. Measure the radioactivity in a liquid scintillation counter.

These samples correspond to the CELL WALL GALACTOMANNAN fraction (Fig. 1A).

\section{Analysis of the results}

All determinations are performed in duplicate, and data for each strain should be calculated from at least three independent experiments.

Before analysis, each sample radioactivity is normalized calculating the counts in the total volume (Fig. 1A):

1. Cells: average counts $x 1000 / 50$ 
2. Cell wall: average counts $x 1000 / 50$

3a. Zymolyase-100T pellet: average counts $\mathrm{x} 1000$ / 50

3b. Quantazyme pellet: average counts x $1000 / 50$

3c. Chemical fractionation of galactomannan: Average counts x $1000 / 200$

The first important data of this analysis is the \% of cell wall respect to the cell, which may show relevant general cell wall defects.

Note that the cell wall percentage with respect to total glucose incorporation will be different depending on the growth medium and temperature. For example in a standard experiment the cell wall of a wild-type strain grown in YES at $28^{\circ} \mathrm{C}$ is around $30-34 \%$ of total glucose incorporation, whereas in YES + 1.2M sorbitol, MM and MM+1.2M sorbitol is around $24 \%$, $28 \%$, and $22 \%$, respectively. All these percentages increase when the incubation temperature increases.

The cell wall can be divided into three polymers as follows (Fig. 1B):

1. $\alpha$-glucan: pellet of Zymolyase-100T degradation.

2. Galactomannan: pellet of chemical fractionation with Fehling's reagent.

3. $\beta$-glucan: cell wall minus $\alpha$-glucan and galactomannan fractions.

The $\beta$-glucan can be divided into two polymers as follows (Fig. 1B):

3a. $\beta(1,3)$ glucan: cell wall minus pellet of Quantazyme degradation.

3b. $\beta(1,6)$ glucan: total $\beta$-glucan minus $\beta(1,3)$-glucan fraction.

The polysaccharide fractions can be referred as a percentage of total cell wall radioactivity (the sum is $100 \%$ ) or as a percentage of total glucose incorporation into the cell (Fig. 1B). The analysis of these percentages may reveal defects in the proportion of distinct polysaccharides relative to the cell wall, to the cell or to both structures.

\section{REFERENCES}

Algranati, I.D., Behrens, N., Carminatti, H., and Cabib, E. 1966. Mannan synthetase from yeast. Methods Enzymol 8: 411-416.

Kapteyn, J.C., Ram, A.F., Groos, E.M., Kollar, R., Montijn, R.C., Van Den Ende, H., Llobell, A., Cabib, E., and Klis, F.M. 1997. Altered extent of cross-linking of $\beta 1,6$-glucosylated 
mannoproteins to chitin in Saccharomyces cerevisiae mutants with reduced cell wall $\beta 1,3-$ glucan content. J Bacteriol 179: 6279-6284.

Kollar, R., Reinhold, B.B., Petráková, E., Yeh, H.J., Ashwell, G., Drgonová, J., Kapteyn, J.C., Klis, F.M., and Cabib, E. 1997. Architecture of the yeast cell wall. $\beta(1-6)$-glucan interconnects mannoprotein, $\beta$ (1-3)-glucan, and chitin. J Biol Chem 272: 17762-17775.

Muñoz, J., Cortés, J.C., Sipiczki, M., Ramos, M., Clemente-Ramos, J.A., Moreno, M.B., Martins, I.M., Pérez, P., and Ribas, J.C. 2013. Extracellular cell wall $\beta(1,3)$-glucan is required to couple septation to actomyosin ring contraction. J Cell Biol 203: 265-282.

Pérez, P. and Ribas, J.C. 2004. Cell wall analysis. Methods 33: 245-251.

10

11

\section{FIGURE LEGEND}

Figure 1. Scheme of the fractionation (A), and analysis (B) of cell wall polysaccharides.

14 


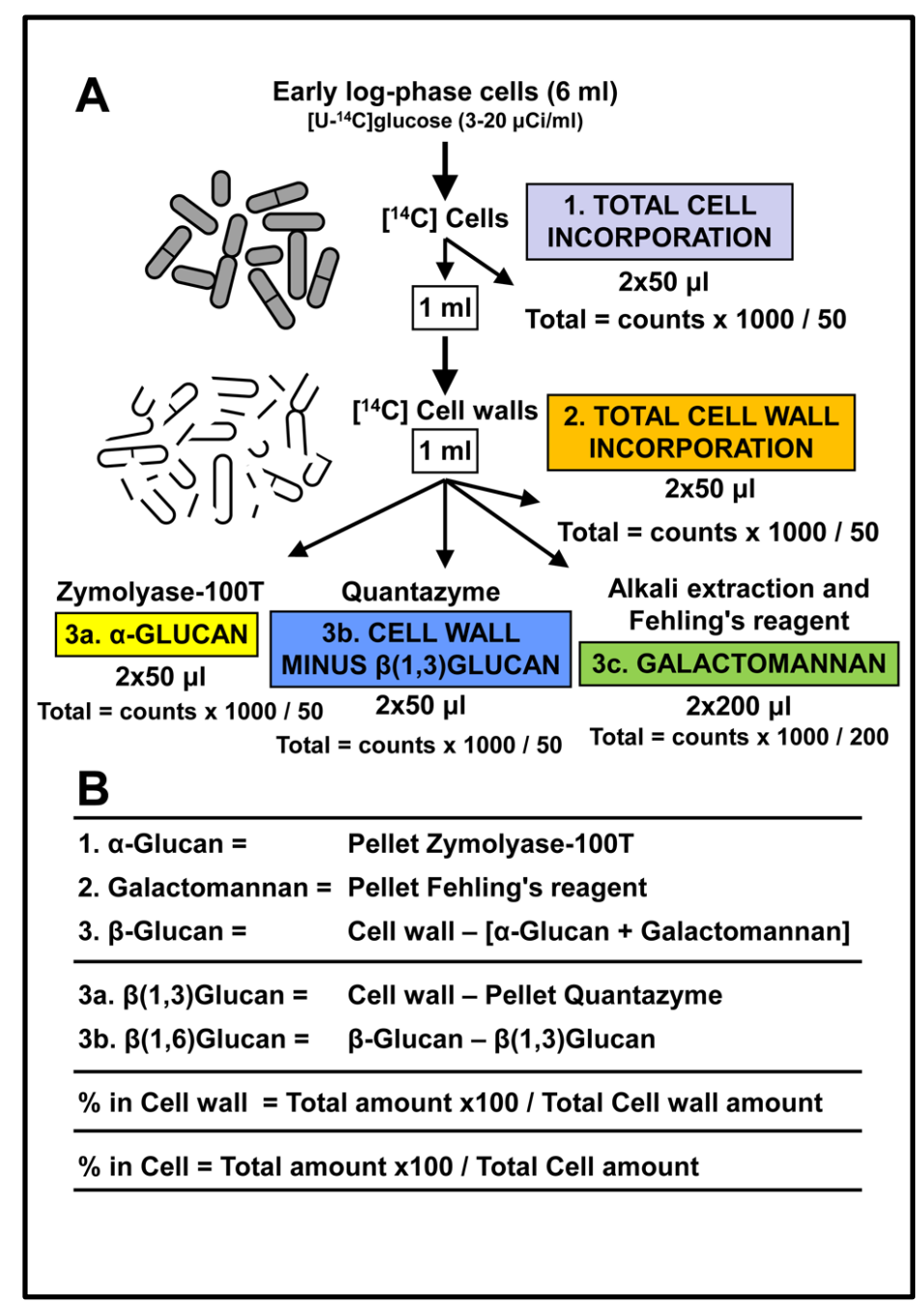

